\title{
ПРОГНОЗУВАННЯ ДИНАМІКИ ЗМІН ПРІОРИТЕТІВ ВИМОГ В МЕТОДІ ЗВОРОТНОГО РОЗПОВСЮДЖЕННЯ ПРІОРИТЕТІВ
}

Анотація: в даній статті розглядається новий алгоритм диспетчеризації матеріальних потоків шляхом зворотного розповсюдження пріоритетів в гнучких виробничих системах, що побудований на базі оптимізаційного алгоритму Дейкстри.

Ключові слова: ГВС, матеріальний потік, накопичувач, оперативне управління, алгоритм Дейкстри, технологічна комірка.

\section{Вступ}

Стаття $є$ продовженням досліджень методу зворотного розповсюдження пріоритетів диспетчеризації матеріальних потоків в гнучких виробничих системах (ГВС) [1].

Одним із перспективних напрямків удосконалення розробленого методу було назване прогнозування відхилень в динаміці змін пріоритетів вимог. Таке прогнозування важливе з тієї точки зору, що у випадку, коли можна заздалегідь спрогнозувати зростання вимоги на певній технологічній комірці (ТК), наприклад, у момент виникнення непередбачуваної події на виробництві, можна отримати швидшу корекцію вимог, а, отже, досягнути швидшого динамічного перепланування розподілу матеріальних потоків i, таким чином, сприяти швидшій нормалізації ситуації всередині ГВС, що мінімізує відхилення від виконання календарного плану виробництва.

\section{Постановка задачі}

Розглянемо ГВС як мережу інтелектуальних агентів, які ведуть неперервне планування своєї діяльності (формують вимоги до отримання деталей, що виражається в пріоритеті $P=[0 . .1]$, який, в свою чергу, складається з пріоритетів на кожному вхідному матеріальному потоці, тобто $P=\sum_{i=1}^{n} p o_{i} \cdot q_{i}$, де $q$ - відносна заповненість накопичувача деталей).

Проблема планування діяльності агентів стає особливо гострою при виникненні нештатних ситуацій в ГВС (наприклад, виходу 3 ладу однієї з технологічної комірки (TК)), в такому випадку, агенти повинні виконати перепланування пріоритетів вимог) [1]. При цьому виконуеться розрив зв'язків між ТК, а отже, змінюються вимоги кожної ТК, бо кожен зв'язок відображає певний вхідний матеріальний потік.

(c) А.М. Дзінько, Л.С. Ямпольський, 2015 
В термінах запропонованого алгоритму виконуеться розрив лише вхідних матеріальних потоків, оскільки агент про виходи необізнаний.

В поточній реалізації алгоритму агенти, що знаходяться на початку технологічного ланцюжка $(B, C)$, отримають вплив з певним запізненням, оскільки зміна вимог за пріоритетами розповсюджується з агентів, що знаходяться в кінці технологічного ланцюжка [1]. Таким чином, для певного агента $A$ (рис. 1 ) вимога $P$ зростатиме дуже повільно за лінійним законом (рис. 2).

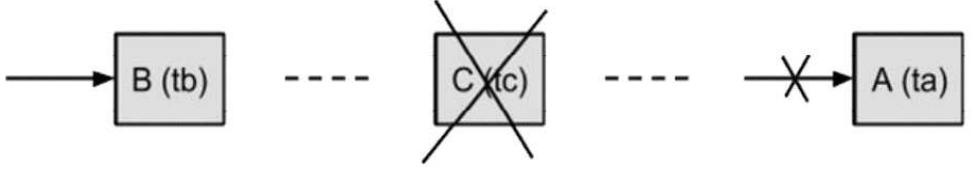

Рис. 1 - Ділянки ГВС, що репрезентовані агентами, де агент $A$ отримує вхідний потік від агента $C$.

Наприклад, якщо час виконання обробки однісї деталі (включаючи час завантаження та розвантаження деталі) становить 20 секунд, а накопичувач представляє собою бункер на 100 деталей, вимога зменшиться вдвічі лише за $20 \times 50=1000 c=16.66(6)$ хв.

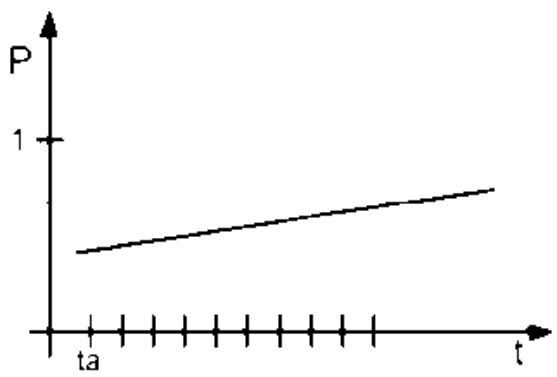

Рис. 2 - Закон зміни вимоги з часом при розриві вхідних потоків.

Очевидно, що така динаміка є неприйнятною, оскільки при виході з ладу ТК, що була одним з джерел матеріального потоку для агента $A$, зменшиться потужність матеріального потоку до цієї комірки, а середня швидкість заповнення накопичувача залишатиметься такою ж.Таким чином, вимога повинна зростати швидше, адже це вже відомо заздалегідь.

\section{Аналіз зміни зв'язків при виникненні нештатних ситуацій в ГВС}

Розглянемо варіанти позиціювання інтелектуальних агентів в мультиагентному середовищі ГВС (рис. 3). 


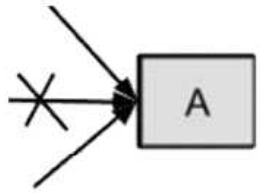

a)

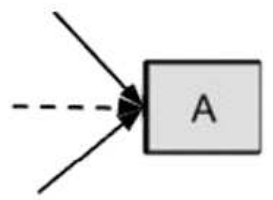

6)

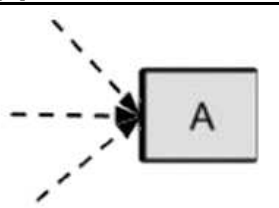

в)

Рис. 3 - Позиціювання агентів в мультиагентному середовищі ГВС: a) розрив матеріального потоку; б) введення нового матеріального потоку; в) введення в експлуатацію резервного агента (ТК).

У випадку, зображеному на рис. 3,a, маємо фракт знищення вхідного матеріального потоку $j$ агента $A$; таким чином, отримуємо зміну розрахунку вимоги агента $P=\sum_{i=1}^{n} p o_{i} \cdot q_{i} \Rightarrow P=\sum_{i=1}^{n-1} p o_{i} \cdot q_{i}+$ $p o_{j} \cdot q_{j} /(n-1)$, тобто вимоги потоку розподіляються рівномірно між рештою вхідних потоків на один наступний дискретний крок зміни стану системи.

У випадку, коли розірваний матеріальний потік був единим отримуємо критичну ситуацію, коли календарний план не може бути виконаним фізично, а, отже, система повинна зупинити розрахунки або ввести додаткового агента, що виконував роль того, що вийшов з ладу.

Розглянувши ситуацію з рис. 3 ,б, бачимо зворотній випадок, коли агент отримує додатковий матеріальний потік. В такому випадку, вимога новоствореного потоку повинна формуватись за рахунок пропорційного зменшення вимог до існуючих потоків.

Виключним є останній випадок (рис. 3, в), що визначає введення резервного агента в експлуатацію. В такому випадку, агент повинен отримати рівень вимоги як і у випадку, коли система тільки розпочинае роботу, тобто $P=\sum_{i=1}^{n} 1 / n=1$.

\section{Оптимізація часу адаптації системи шляхом введення коефіціента зміни динаміки вимог}

У будь-якому випадку, незалежно від позиціювання, посилення динаміки зміни вимоги по пріоритетах залежить від певних факторів:

1. Прямопропорційно - від швидкості матеріального потоку (середня швидкість $V t_{c}$ руху $n$ деталей за одиницю часу в потоці).

2. Оберненопропорційно - від швидкості спорожніння накопичувача агента $(V q)$.

Тобто, введемо деякий необхідний коефіціент зміни динаміки вимог $D p=V t_{c} / V q$. Очевидно, що діяти цей коефіцієнт в процесі 
роботи системи повинен не весь час, а до нормалізації рівня наповненості накопичувача, чи стабілізації швидкості подачі деталей у випадку відсутності останнього.

В такому випадку логічним здається задання порогу різниці швидкостей $V n$ таким чином, щоб виконувалась нерівність:

$$
V t_{c}-V q<V n \text {. }
$$

Тобто даний коефіцієнт є адаптивним і застосовуватиметься виключно у випадку, коли нерівність (1) не виконується. В такому випадку, тимчасовий розрахунок вимоги становитиме

$$
P=\sum_{i=1}^{n} p o_{i} \cdot q_{i} \cdot D p .
$$

\section{Висновки}

За результатами проведеної роботи можна зробити декілька важливих висновків як по розвитку, так і оптимізації існуючих алгоритмічних процедур.

Алгоритм зворотного розповсюдження пріоритетів має визначені процедури диспетчеризації матеріальних потоків як при виведенні обладнання з ладу, так і при введенні додаткового обладнання.

По-друге, була проведена оптимізація роботи алгоритму шляхом введення додаткової процедури корекції динаміки зміни вимог $D p$. При перевірці на імітаційних моделях, така оптимізація дає до 5\% приросту швидкості адаптації системи при виникненні надзвичайних ситуацій. Таким чином виконується прогнозування зростання чи спадання вимог, і цей процес штучно прискорюеться.

Сдиним недоліком процедури є те, що виникає деякий період часу, коли наступає надмірна корекція. В якості подальших досліджень в даному напрямку пропонуеться розглянути використання нейронних мереж для прогнозування часових рядів [2], що репрезентують нестаціонарні процеси.

\section{Список використаних джерел}

1. Ялипольський Л.С. Гнучкі комп'ютеризовані системи: проектування, моделювання і управління: Підручник / Л.С. Ямпольський, П.П. Мельничук, Б.Б. Самотокін, М.М Поліщук, М.M Ткач, К.Б. Остапченко, О.I. Лісовиченко. - Житомир: ЖДДУ, 2005. - 680 c.

2. Рассел C., Норвиг П. Искусственный интеллект: современный подход, 2-е изд.. : Пер. с англ. - М. : Издательский дом “Вильямc", 2006. - 1408 с. : ил. - Парал. тит. англ.

3. Дзінько P.I. Підвищення відмовостійкості фрункціонування ГВС за допомогою прихованих марківських моделей / P.I. 
Дзінько, О.І. Лісовиченко // Адаптивні системи автоматизованого управління: міжвідомчий науково-технічний збірник. - Київ: Національний технічний університет України "Київський політехнічний інститут". - 2013. - № 2(23). - c.18-22.

4. Дзінько А.М. Диспетчеризація матеріальних потоків з динамічною корекцією шляхом оберненого розповсюдження пріоритетів / А.М. Дзінько // Адаптивні системи автоматизованого управління: міжвідомчий науково-технічний збірник. - Кийв: Національний технічний університет України "Київський політехнічний інститут”. - 2014. -№ 1(24). - c.5-6.

Отримано 10.04.2015 p. 